\title{
Exploring the Social Security Benefit Implications of Same-Sex Marriage
}

\author{
Michael S. Pollard and Italo Lopez-Garcia
}




\title{
Exploring the Social Security Benefit Implications of Same-Sex Marriage
}

\author{
Michael S. Pollard \\ RAND Corporation \\ Italo Lopez-Garcia \\ RAND Corporation
}

September 2017

\author{
Michigan Retirement Research Center \\ University of Michigan \\ P.O. Box 1248 \\ Ann Arbor, MI 48104 \\ www.mrrc.isr.umich.edu \\ (734) 615-0422
}

\section{Acknowledgements}

The research reported herein was performed pursuant to a grant from the U.S. Social Security Administration (SSA) funded as part of the Retirement Research Consortium through the University of Michigan Retirement Research Center Award RRC08098401-09. The opinions and conclusions expressed are solely those of the author(s) and do not represent the opinions or policy of SSA or any agency of the federal government. Neither the United States government nor any agency thereof, nor any of their employees, makes any warranty, express or implied, or assumes any legal liability or responsibility for the accuracy, completeness, or usefulness of the contents of this report. Reference herein to any specific commercial product, process or service by trade name, trademark, manufacturer, or otherwise does not necessarily constitute or imply endorsement, recommendation or favoring by the United States government or any agency thereof.

Regents of the University of Michigan

Michael J. Behm, Grand Blanc; Mark J. Bernstein, Ann Arbor; Shauna Ryder Diggs, Grosse Pointe; Denise Ilitch, Bingham Farms; Andrea Fischer Newman, Ann Arbor; Andrew C. Richner, Grosse Pointe Park; Ron Weiser, Ann Arbor; Katherine E. White, Ann Arbor; Mark S. Schlissel, ex officio 


\title{
Exploring the Social Security Benefit Implications \\ of Same-Sex Marriage
}

\begin{abstract}
Same-sex marriage became legal nationwide in the United States on June 26, 2015. Federal legalization of same-sex marriage expands the pool of individuals potentially eligible for spousal Social Security benefits to the estimated 4 percent of the population that is lesbian, gay, or bisexual. This paper is a foundational step toward better understanding the potential impact of the expansion of marriage rights to same-sex couples on Social Security. We primarily use data from the 2011-2015 American Community Survey to describe the economic circumstances of couple households. Building on this information, we find that same-sex couples tend to have higher household earnings than heterosexual couples, especially male couples. We estimate that same-sex couples have a smaller earnings gap (up to 4 percentage points) compared with heterosexuals. Intrahousehold division of labor explains 58 to 66 percent of the observed smaller earnings gaps in same-sex versus heterosexual couples.

Same-sex married couples are less likely than heterosexuals to qualify for spousal SS benefits, but given that they are eligible, males can generally claim higher benefit amounts than heterosexuals (about $\$ 8,400$ /year), while female couples could claim similar amounts to heterosexuals (about \$7,200 /year). We project spousal benefit claims for same-sex couples 2017 to 2040, using standard demographic methods to estimate the gay and lesbian population by age and sex for this period.

Finally, we collect new data that confirm the results obtained from the ACS, and provide insights about subjective expectations about marriage and labor supply prospects for this population. These can be used for future estimations.
\end{abstract}

\section{Citation}

Pollard, Michael S., and Italo Lopez-Garcia. 2017. "Exploring the Social Security Benefit Implications of Same-Sex Marriage.” Ann Arbor, MI: University of Michigan Retirement Research Center (MRRC) Working Paper, WP 2017-377.

http://www.mrrc.isr.umich.edu/publications/papers/pdf/wp377.pdf

\section{Authors' acknowledgements}

We thank Andriy Bega for assistance with the analyses. This research uses data from Add Health, a program project designed by J. Richard Udry, Peter S. Bearman, and Kathleen Mullan Harris, and funded by a grant P01-HD31921 from the National Institute of Child Health and Human Development, with Cooperative funding from 17 other agencies. Special acknowledgment is due Ronald R. Rindfuss and Barbara Entwisle for assistance in the original design. Persons interested in obtaining data files from Add Health should contact Add Health, Carolina Population Center, 123 W. Franklin Street, Chapel Hill, NC 27516-2524 (addhealth@unc.edu). 


\section{Introduction}

Same-sex marriage became legal nationwide in the United States on June 26, 2015. Prior to federal legalization, there was a sharp increase in the number of same-sex married couples, from about 150,000 in 2010 when it was legal only in five states, to an estimated 390,000 same-sex married couples in 2015, when it was legal in more than 30 states. Recent estimates from Gallup (Jones 2016) suggest that by 2016 there were approximately 490,500 same-sex married couples, which matches other predictive estimates that federal legalization could rapidly expand the number of same-sex marriages to 500,000 (Schwarz 2015). Federal legalization of same-sex marriage expands the pool of individuals potentially eligible for spousal retirement benefits from Social Security (SS) through the Social Security Administration (SSA). Currently, no estimates of this potential impact exist. This paper provides early estimates of the potential impact to Social Security claims of the expansion of spousal benefits to same-sex couples.

Despite the rapid growth of legal same-sex marriage, the vast majority of research on couples focuses exclusively on heterosexual couples. Further, largely due to data limitations, the scant research on same-sex couples has tended to focus on younger, rather than older, couples (e.g., Joyner, Manning \& Bogle 2013). We know relatively little about adult same-sex couple households, about the economic circumstances of the couple members, or the implications of legal same-sex marriage for Social Security. Analysis of individuals ages 24 to 32 in 2009 suggests that approximately 4 percent of the population identifies as lesbian, gay, or bisexual (LGB), and could potentially qualify for future Social Security benefits in same-sex marriages (Meadows et al. 2010). According to current U.S. Census Bureau national population estimates, this translates to roughly 10 million LGB individuals, but it is unknown how many same-sex marriages this could potentially reflect. This paper establishes estimates of the projected number 
of gay and lesbian individuals by age, as well as same-sex marriages over time, in order to estimate the impact of legalized same-sex marriage on Social Security benefits.

Prior research suggests that earnings are lower for gay men relative to heterosexual men (between 14 percent and 30 percent), and for lesbian women relative to heterosexual women (between 20 percent and 34 percent), although results are sensitive to time period considered and measures of orientation (Black et al. 2003; Carpenter 2005). Further, unmarried same-sex partners are vulnerable to economic disadvantage relative to married partners in the event of divorce or death of a partner limiting access to financial support or benefits. It is imperative that we develop a better understanding of the economic circumstances of the LGB population, single and married, in order to assess age trends and the impacts on Social Security.

Under Social Security current provisions, individuals can receive spousal benefits equal to 50 percent of their spouse's benefits. Spouses who are eligible for larger benefits based on their own earnings history typically collect their own Social Security benefit rather than the spousal benefit. Individuals who were married for 10 years and are now divorced (and did not remarry) are also eligible to receive spousal benefits. Widows may claim up to the full amount of their deceased spouse's benefit. The division of labor and disparity between partner incomes in samesex married households is unknown. It is also unknown how this intrahousehold allocation of labor and resources evolves over the life-course. In addition to estimating the extent to which same sex couples are likely to marry, a full picture of the potential impact requires estimates of the difference in incomes and labor force participation between same-sex partners. Expansion of marriage expands the set of individuals eligible for spousal benefits. However, if partners earn relatively similar incomes, then there is no incentive (or ability) to claim spousal benefits. In traditional heterosexual couples, wives are more likely to claim benefits based on their husbands' incomes because of significant income disparities due to child rearing and income 
discrimination, for example. However, for same-sex couples it is not clear that we should expect income differences within homosexual couples to mirror those within heterosexual couples. While increasingly common, child rearing within same-sex couples is less prevalent than among heterosexual couples. Furthermore, partners in same-sex couples would face the same sex-based wage discrimination. Throughout this report, we focus on currently-married couples to facilitate benefits assessments.

This paper is the first foundational step in a research agenda designed to better understand the potential impact of the expansion of marriage rights to same-sex couples on Social Security, and on labor market outcomes of couple members such as income and labor market participation. We begin examining the economic circumstances of same-sex couples and of LGB individuals using new nationally-representative data, to anticipate the future prevalence of same-sex married couples, and consider the implications for future Social Security benefit payments under legalized same-sex marriage. Specifically, we:

1. Describe the economic circumstances of adult same-sex couples in nationally representative data;

2. Assess the division of labor within same-sex households to assess degree of specialization in domestic versus market production;

3. Estimate the current number of same-sex couples that would meet federal eligibility requirements for Social Security benefits, and estimate the amount of benefits eligible to be claimed;

4. Estimate, using demographic methods, the number of gay and lesbian individuals over time, and estimate the numbers of same-sex marriages based on new data regarding intentions to marry among gays and lesbians; and 
5. Collect new data on earnings and labor supply status, as well as individual information on sexual orientation based on self-identification, attraction, and experience, subjective expectations about marriage, labor supply, and the claiming of Social Security benefits, and knowledge of spousal benefits.

The data for this project comes from a variety of nationally representative sources: the 20112015 American Community Survey (ACS), The National Longitudinal Study of Adolescent to Adult Health (Add Health), the Health and Retirement Study (HRS), and the RAND American Life Panel (ALP).

American Community Survey: The U.S. Census Bureau's 2011-15 ACS explicitly identified married and unmarried same-sex couples for the first time. The ACS in an ongoing, mandatory annual survey conducted by the U.S. Census Bureau to provide information for intercensal periods. Couple households in the ACS are identified when the householder identifies another individual in the household who is 16 or older as his or her "husband/wife" or "unmarried partner.” Respondents also provide information about the sex of the householder and spouse or partner such that same-sex and different-sex couples can be identified. The ACS estimates are period estimates; when precision of estimates is more important that currency of estimates, the U.S. Census Bureau recommends using the five-year ACS estimates rather than the one-year estimates. Thus, we rely on the five-year ACS estimate file (see Beaghen and Weidman, 2008).

Add Health. Add Health follows a nationally representative, school-based sample of 20,745 adolescents in grades 7 to 12 when originally surveyed during the 1994-1995 academic year. Respondents were interviewed at home four times, most recently in 2008, when they were ages 24 to 32. To our knowledge, Add Health is the largest longitudinal survey to include questions 
regarding sexual orientation, and the data cover a relatively long period. As previously noted, roughly 4 percent of Add Health respondents report LGB status. ${ }^{1}$

The Health and Retirement Study. The HRS is a panel study that began in 1992, reinterviews people biannually, and is currently representative of all persons older than 50 in 1998 . The HRS includes detailed longitudinal financial information, which is used in this study to validate a key assumption about earnings trajectories of LGB and heterosexual individuals. We use 12 waves from 1992 to 2014.

The RAND ALP. The ALP (https://alpdata.rand.org) is an ongoing, nationally representative, longitudinal internet panel of individuals 18 and older. At recruitment into the panel, those who report not having access to the internet at the time are provided with a laptop, including an Internet access subscription with an email account. As a result, the sample does not suffer from selection as a function of Internet access. Interview data are reweighted to match Current Population Survey distributions on demographic characteristics and income. Sample size is about 5,000 persons. Response rates are approximately 80 percent. Panel member sexual orientation was collected in 2015. The sample contains 138 gay/lesbian and 109 bisexual respondents, which is in line with estimated population prevalence. As part of this project we designed and fielded a special survey to the LGB respondents in the ALP, focusing on same-sex relationships and marriage. The survey collected detailed information on the incomes of both partners in LGB couples. The survey also collected information on LGB respondent attitudes toward intention to marry, retirement timing expectations, and knowledge of Social Security spousal benefits. For more details on the RAND ALP, please refer to Pollard and Baird (2017).

\footnotetext{
${ }^{1}$ Further details regarding sample design and weights are available at: http://www.cpc.unc.edu/projects/addhealth/
} 


\section{Economic circumstances of Same-Sex and Heterosexual Couples in the 2011-2015 ACS}

Table 1 presents the 2011-15 ACS estimates of the counts of couple households. The estimates may be interpreted as the averages during the period. According to the ACS, there were approximately 729,000 same-sex married and cohabitating couples (1.15 percent), as shown below. Of these 729,000 same-sex couples, only 28 percent reported being married to their partners, compared to 89 percent of heterosexual couple households. This estimate is somewhat lower than a more recent 2016 Gallup poll which indicated that 49 percent of surveyed same-sex households were married (Jones 2016). Note that the ACS data predate the national legalization of same-sex marriage, and thus the lower numbers of marriages are expected.

Table 1. Number of opposite-sex and same-sex couples

\begin{tabular}{lrr}
\hline Relationship type & Number of couples & Percent \\
\hline \hline Married (hetero) & $56,207,015$ & $88.48 \%$ \\
Cohabiting (hetero) & $6,585,752$ & $10.37 \%$ \\
Married S-S (male) & 96,171 & $0.15 \%$ \\
Married S-S (female) & 106,944 & $0.17 \%$ \\
Cohabiting S-S (male) & 253,925 & $0.40 \%$ \\
Cohabiting S-S (female) & 271,827 & $0.43 \%$ \\
\hline Total & $63,521,634$ & $100 \%$ \\
\hline \hline
\end{tabular}

\section{Employment status}

To examine couples’ employment patterns, we divided couples into four types: both employed, one employed, both unemployed, and retired. A person is unemployed if he/she did not work during the past 12 months and, respectively, had zero earnings. We defined a couple as retired if at least one of the partners is 62 or older and did not work for the past 12 months. Table 2 shows the percent of couples by relationship type that are likely to be both employed in comparison with couples in which only one partner is employed, among couples in which at least one partner is active in the labor force. Partners in married, same-sex couples are much more likely to be 
both employed than in heterosexual marriages, with likelihoods of 80.4 percent and 79.3 percent for same-sex married males and females, respectively, and 72.0 percent for married heterosexual. Differences are smaller among cohabitating couples, but the pattern still persists.

Table 2. Percent of couples by employment status

\begin{tabular}{lcc}
\hline Relationship type & Both employed & One employed (\%) \\
\hline Married (hetero) & $72.0 \%$ & $28.0 \%$ \\
Cohabiting (hetero) & $76.2 \%$ & $23.8 \%$ \\
Married S-S (male) & $80.4 \%$ & $19.6 \%$ \\
Married S-S (female) & $79.3 \%$ & $20.7 \%$ \\
Cohabiting S-S (male) & $81.9 \%$ & $18.1 \%$ \\
Cohabiting S-S (female) & $81.4 \%$ & $18.6 \%$ \\
\hline Total & $72.6 \%$ & $27.4 \%$ \\
\hline \hline
\end{tabular}

We study whether relationship type matters for the couple's employment status in a regression approach. We are interested in testing whether same-sex couples are more likely to be both employed as shown in Table 2 after controlling for sociodemographic characteristics. Table 3 shows the result of a probit regression in which there is a binary dependent variable equal to 1 if both partners are employed, and 0 if only one is employed. The results confirm the findings of Table 2 that same-sex couples have higher probabilities of being both employed: Male same-sex married couples are 8.98 percent more likely to be both employed than heterosexual married couples and female same-sex married, 3.3 percent more likely.

\section{Earnings}

We study couple earnings and earnings gaps between partners by relationship type looking at the reported earnings of the household head (primary respondent on the survey) and his/her spouse. All other sources of income and earnings from other household members are ignored. The median joint couple earnings, where at least one partner has nonzero earnings, are presented in Table 4. 
Table 3. Coefficients and average marginal effects of couple's employment status model

Probit Regression. Dependent Variable: Coeff. ME

Both are employed vs. One employed

\begin{tabular}{|c|c|c|}
\hline \multicolumn{3}{|l|}{ Relationship type (base: Married hetero) } \\
\hline Cohabiting (hetero) & $\begin{array}{c}0.0487 * * * \\
(0.000)\end{array}$ & $\begin{array}{c}0.0156^{* * *} \\
(0.000)\end{array}$ \\
\hline Married S-S (male) & $\begin{array}{c}0.309 * * * \\
(0.000)\end{array}$ & $\begin{array}{c}0.0898 * * * \\
(0.000)\end{array}$ \\
\hline Married S-S (female) & $\begin{array}{c}0.107 * * * \\
(0.000)\end{array}$ & $\begin{array}{c}0.0336 * * * \\
(0.000)\end{array}$ \\
\hline Cohabiting S-S (male) & $\begin{array}{c}0.387 * * * \\
(0.000)\end{array}$ & $\begin{array}{c}0.109 * * * \\
(0.000)\end{array}$ \\
\hline Cohabiting S-S (female) & $\begin{array}{c}0.179 * * * \\
(0.000)\end{array}$ & $\begin{array}{l}0.0548^{* * *} \\
(0.000)\end{array}$ \\
\hline Male & $\begin{array}{c}-0.163 * * * \\
(0.000)\end{array}$ & $\begin{array}{l}-0.0529 * * * \\
(0.000)\end{array}$ \\
\hline Age & $\begin{array}{c}-0.0860 * * * \\
(0.000)\end{array}$ & $\begin{array}{c}-0.0279 * * * \\
(0.000)\end{array}$ \\
\hline Age squared & $\begin{array}{c}0.000926^{* * *} \\
(0.000)\end{array}$ & $\begin{array}{c}0.000300 * * * \\
(0.000)\end{array}$ \\
\hline \multicolumn{3}{|c|}{ Other controls: Age gap between partners, Education, Couple earnings, Race, } \\
\hline $\begin{array}{l}\text { Observations } \\
\text { Note: } * \mathrm{p}<0.05, * * \mathrm{p}<0.01, * * * \mathrm{p}<0.001\end{array}$ & & $2,338,411$ \\
\hline
\end{tabular}

Table 4. Median couple earnings

\begin{tabular}{lccc}
\hline Relationship type & Both & One & Total \\
\hline \hline Married (hetero) & $\$ 89,853$ & $\$ 49,362$ & $\$ 74,431$ \\
Cohabiting (hetero) & $\$ 61,513$ & $\$ 25,032$ & $\$ 50,757$ \\
Married S-S (male) & $\$ 115,145$ & $\$ 61,513$ & $\$ 97,395$ \\
Married S-S (female) & $\$ 96,922$ & $\$ 44,422$ & $\$ 80,767$ \\
Cohabiting S-S (male) & $\$ 103,130$ & $\$ 45,057$ & $\$ 88,843$ \\
Cohabiting S-S (female) & $\$ 80,767$ & $\$ 32,193$ & $\$ 69,087$ \\
\hline Total & $\$ 85,815$ & $\$ 45,070$ & $\$ 70,974$ \\
\hline \hline
\end{tabular}

Among couples in which both partners are employed, same-sex married couples and same-sex cohabitating men earn more than heterosexual couples (\$115,145 and \$96,922 for same-sex male and female, respectively, and $\$ 89,853$ for married heterosexual). However, among couples in which only one partner is employed, only same-sex married men earn substantially more than married hetero 
couples ( $\$ 61,513$ and $\$ 49,362$, respectively), while other types of same-sex couples (married or cohabitating) earn less. Cohabitating women have the lowest earnings among same-sex couples, possibly reflecting labor market discrimination effects.

Figure 1 reports distributional comparisons across different types of couples by incomes based on the lower earner. This figure highlights that same-sex couples of all types tend to have income distributions that are shifted to the right - that is, they generally have a smaller proportion of couples with incomes at the lowest end of the income distribution, and substantially larger proportions with higher incomes.

Figure 1. Percent of Couples by Lower Earner's Income, by Couple Type, ACS 2011-2015

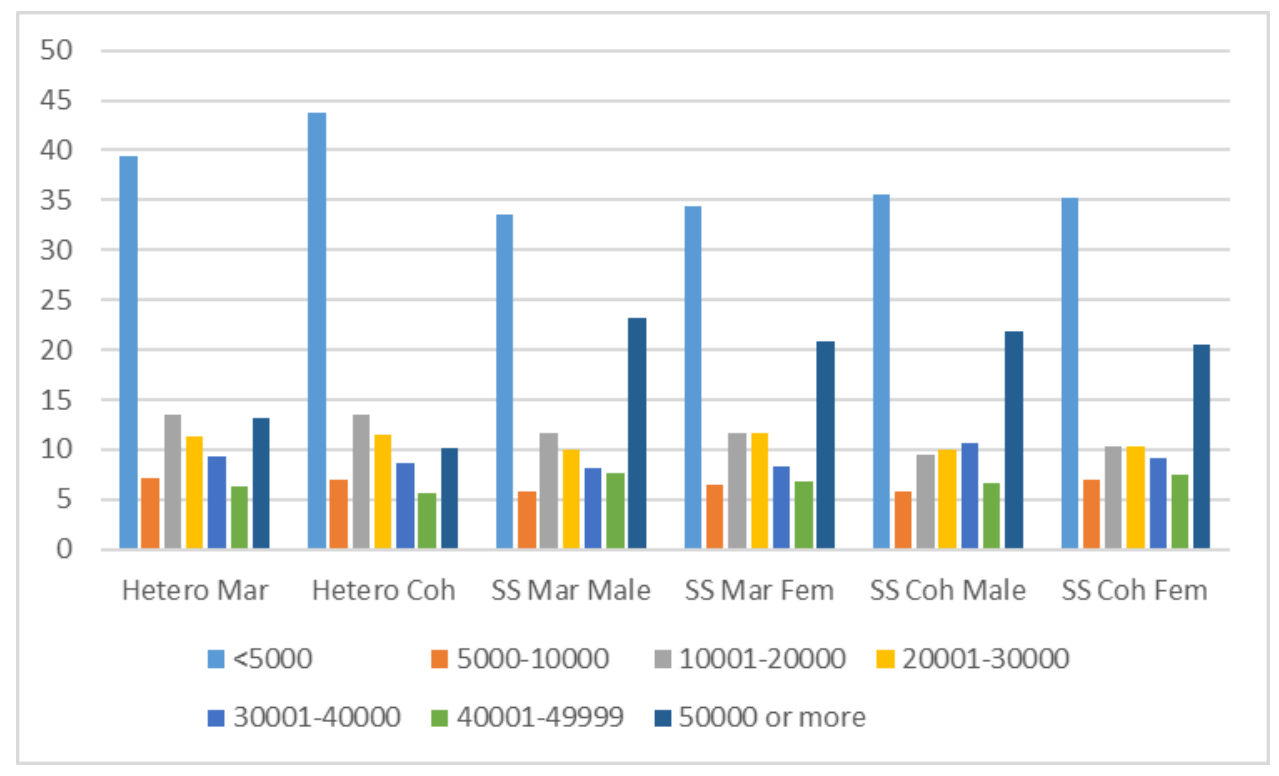

A critical aspect of spousal Social Security benefits is that there must be a significant gap between the earnings of partners in order to meet the requirement that one-half of the higher earning partner's benefits are greater than the lower earning partner's full benefit. Table 5 presents the mean dollar value of the earnings gap between partners in different types of couple households. We observe that if both are employed, the earning gap among same-sex male married and cohabitating couples is $\$ 60,932$ and $\$ 53,299$, respectively, while among married heterosexuals is $\$ 44,733$ and for same-sex female married is $\$ 42,400$. 
Table 5. Earnings Gap between couple members by relationship type

\begin{tabular}{lcc}
\hline Relationship type & Both Employed & One \\
\hline \hline Married (hetero) & $\$ 44,733$ & $\$ 75,826$ \\
Cohabiting (hetero) & $\$ 26,475$ & $\$ 33,828$ \\
Married S-S (male) & $\$ 60,392$ & $\$ 105,826$ \\
Married S-S (female) & $\$ 42,400$ & $\$ 67,767$ \\
Cohabiting S-S (male) & $\$ 53,299$ & $\$ 69,935$ \\
Cohabiting S-S (female) & $\$ 34,647$ & $\$ 50,688$ \\
\hline Total & $\$ 42,418$ & $\$ 71,314$ \\
\hline \hline
\end{tabular}

Table 6 presents the earnings gap between partners as a percentage of the couple’s total earnings, in order to account for the differences in earning levels across couple types. While male same-sex married households have larger total earnings, which suggest larger dollar value differences between partner earnings are possible, they may reflect similar proportional differences compared to other couple types. This is important because it suggests that the incentives to claim spousal benefits upon retirement should not be really different among different types of relationship arrangements.

Table 6. Earnings Gap as percent of couples' joint earnings

\begin{tabular}{lc}
\hline Relationship type & Both Employed \\
\hline \hline Married (hetero) & $39 \%$ \\
Cohabiting (hetero) & $35 \%$ \\
Married S-S (male) & $39 \%$ \\
Married S-S (female) & $36 \%$ \\
Cohabiting S-S (male) & $36 \%$ \\
Cohabiting S-S (female) & $34 \%$ \\
\hline Total & $39 \%$ \\
\hline \hline
\end{tabular}

We further test for this result in a regression approach, controlling for a rich set of couple’s sociodemographic characteristics and for couple’s employment status. Controlling for employment status is important because if earnings gaps are mostly driven by labor supply choices then other factors, driving differences in intrahousehold division of labor across types of relationships, such as relationship instability and expectations about the future, should be taken into consideration. 
We study the following regression:

$$
Y_{i}=\alpha+X_{i} \beta+Z_{i} \gamma+\varepsilon_{i}
$$

Where $Y_{i}$ is earning gap as percent of couple's earnings, $X_{i}$ - couple's relationship status, and $Z_{i}-$ other couple’s characteristics, which include gender of the main respondent, age of the older partner, age gap between partners, couple’s employment status, earnings quintiles, education of better-educated partner, dummy if partners have the same level of education, race, and region. We have also tried several specifications of relationship type interaction with age difference, age, and with earnings quintile.

Table 7 presents the results of these regressions after controlling for couple’s sociodemographic variables. We find that, before controlling labor supply in specification 1, same-sex relationship is associated with a smaller earning gap of about 4.1 percent among men and 6 percent among women compared to heterosexual couples. However, when dummies for work status of the couple are included as controls in specification 2, earnings gaps for same-sex couples are only 1.36 percent lower for males and 1.46 percent smaller for females. That is, most of the variation in earnings gaps in percentages is driven by dummies of couple's employment status, confirming the hypothesis of the need for a deeper examination of what determines joint labor supply choices across different couple arrangements. If we add interaction terms, earnings-gap differences in comparison with married heterosexual couples remain statistically significant. For male same-sex married couples the gap is -1.7 percent lower than married heterosexuals, and the same percentages are -1.5 percent for females same-sex married. Comparing specifications 1 to 2 or 3, our interpretation is that differences in intrahousehold division of labor between same-sex and heterosexual couples explain between 58 percent and 66 percent of the observed differences in earnings gaps between these couples. 
Table 7. Coefficients and marginal effects from the regression of percent earning difference

\begin{tabular}{|c|c|c|c|c|}
\hline \multirow[b]{2}{*}{ Relationship type } & \multirow{2}{*}{$\begin{array}{c}\text { (1) } \\
\text { Coeff. }\end{array}$} & \multirow{2}{*}{$\begin{array}{c}(2) \\
\text { Coeff. }\end{array}$} & \multicolumn{2}{|c|}{ (3) } \\
\hline & & & Coeff. & ME \\
\hline Married (hetero) & 0 & 0 & 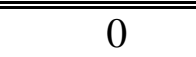 & 0 \\
\hline Cohabiting (hetero) & $\begin{array}{c}\mathbf{- 8 . 4 6 0} \\
(0.000)\end{array}$ & $\begin{array}{c}1.082 \\
(0.000)\end{array}$ & $\begin{array}{c}0.627 \\
(0.000)\end{array}$ & $\begin{array}{c}1.005 \\
(0.000)\end{array}$ \\
\hline Married S-S (male) & $\begin{array}{l}-4.110 \\
(0.000)\end{array}$ & $\begin{array}{c}-1.360 \\
-(0.001)\end{array}$ & $\begin{array}{l}-3.184 \\
(0.000)\end{array}$ & $\begin{array}{l}-\mathbf{- 1 . 7 3 1} \\
(0.000)\end{array}$ \\
\hline Married S-S (female) & $\begin{array}{l}\mathbf{- 6 . 0 2 2} \\
(0.000)\end{array}$ & $\begin{array}{l}-\mathbf{- 1 . 4 5 9} \\
(0.000)\end{array}$ & $\begin{array}{c}-1.694 \\
-(0.028)\end{array}$ & $\begin{array}{l}\mathbf{- 1 . 5 4 4} \\
(0.000)\end{array}$ \\
\hline Cohabiting S-S (male) & $\begin{array}{l}\mathbf{- 9 . 5 9 9} \\
(0.000)\end{array}$ & $\begin{array}{l}-1.255 \\
-(0.109)\end{array}$ & $\begin{array}{c}0.226 \\
-(0.886)\end{array}$ & $\begin{array}{c}\mathbf{- 1 . 0 4 8} \\
-(0.200)\end{array}$ \\
\hline Cohabiting S-S (female) & $\begin{array}{c}\mathbf{- 1 1 . 4} \\
(0.000)\end{array}$ & $\begin{array}{c}\mathbf{- 0 . 8 5 7} \\
-(0.066)\end{array}$ & $\begin{array}{c}-1.353 \\
-(0.191)\end{array}$ & $\begin{array}{c}-\mathbf{0 . 9 4 6} \\
-(0.066)\end{array}$ \\
\hline Interaction terms & None & None & \multicolumn{2}{|c|}{ Relationship type \# Age Gap } \\
\hline \multicolumn{5}{|l|}{ Controls } \\
\hline $\begin{array}{l}\text { Work status couple } \\
\text { Socio-demograhics }\end{array}$ & $\begin{array}{l}\text { No } \\
\text { Yes }\end{array}$ & $\begin{array}{l}\text { Yes } \\
\text { Yes }\end{array}$ & $\begin{array}{l}\text { Yes } \\
\text { Yes }\end{array}$ & \\
\hline
\end{tabular}

As the final piece of the earnings analysis, we report the analysis of individual earnings trajectories using longitudinal data from the Health and Retirement Study, waves 1 (1992) to 12 (2014). Table 8 shows regressions of earnings in each wave on polynomials of age, earnings in wave 1, and dummies for same-sex interacted with age polynomials. As these latter dummies are all statistically zeros we can conclude that LGB individuals do not have different earnings trajectories than heterosexual individuals over the life-cycle once we account for individual heterogeneity. If that was the case, it could potentially invalidate our analysis on earnings differences based on cross-sectional data. Additional regressions incorporating age categories instead of polynomials, including individual fixed effects, and controlling by cohorts, lead to the same conclusion (results not shown). 
Table 8. Regressions of earnings trajectories, 1992-2014 HRS

\begin{tabular}{|c|c|}
\hline Dependent Variable: Annual deflated earnings, HRS Waves & OLS \\
\hline Age & $\begin{array}{c}2342.07^{* * *} \\
(0.000)\end{array}$ \\
\hline Age squared & $\begin{array}{c}-24.78^{* * *} \\
(0.000)\end{array}$ \\
\hline Base Earnings & $\begin{array}{c}0.659 * * * \\
(0.000)\end{array}$ \\
\hline Same sex & $\begin{array}{c}14431.92 \\
(0.773)\end{array}$ \\
\hline Same sex $*$ age & $\begin{array}{c}1692.086 \\
(0.447)\end{array}$ \\
\hline Same sex $*$ age $^{\wedge} 2$ & $\begin{array}{l}-24.43 \\
(0.315)\end{array}$ \\
\hline \multicolumn{2}{|l|}{ Controls } \\
\hline Wave dummies & Yes \\
\hline $\begin{array}{l}\text { Observations } \\
\text { Note: } * \mathrm{p}<0.05, * * \mathrm{p}<0.01, * * * \mathrm{p}<0.001\end{array}$ & 73,656 \\
\hline
\end{tabular}

\section{Spousal Social Security Retirement Benefit Estimates}

Social Security benefits depend on date of birth, on earnings history, and on retirement timing. In order to estimate the likely benefits to be received by individuals, we rely on information from the SSA Benefits Calculator tool, available at the SSA website. ${ }^{2}$ Further details of how the SSA calculator estimates earnings histories are provided on the website, ${ }^{3}$ but generally the past earnings are estimated based on three features (current earnings at a specific age, the national average wage indexing series, and a relative growth factor initially set to 2 percent), and assumes that individuals have equivalent future earnings up until they start receiving retirement benefits. For simplicity, we assume that individuals retire at normal retirement age (NRA) - the age at which retirement benefits are equal to the “primary insurance amount” (i.e., neither reduced for early retirement, nor increased for delayed

\footnotetext{
2 https://www.ssa.gov/OACT/quickcalc/index.html

3 https://www.ssa.gov/OACT/quickcalc/faqs.html\#8
} 
retirement). Broadly, for individuals born in 1937 and earlier, NRA was age 65. For those born 194354, NRA was 66, and for those born 1960 and later it is 67.

We first estimated the percent of couples observed in the ACS in which the earnings gap between partners likely qualifies them to claim spousal benefits (i.e., the lower earning partner's SSA benefit is likely to be lower than half of the higher earning partner's benefit, based on the SSA calculator). Table 9 presents the percent of couples hypothetically eligible for spousal benefits if they were married, by couple type and age.

Table 9. Percent of couples eligible for spousal benefits by claimant age and couple type, ACS 2011-2015

\begin{tabular}{|l|r|r|r|}
\hline Relationship type & Age 45-54 & Age 55-64 & Age 65+ \\
\hline Hetero married & $46.1 \%$ & $53.5 \%$ & $52.0 \%$ \\
\hline Hetero cohabiting & $43.2 \%$ & $51.5 \%$ & $42.5 \%$ \\
\hline Same-sex married & & & \\
male & $36.2 \%$ & $47.8 \%$ & $45.5 \%$ \\
\hline Same-sex married & & & \\
female & $37.9 \%$ & $46.3 \%$ & $51.8 \%$ \\
\hline Same-sex & $34.6 \%$ & $45.3 \%$ & $44.8 \%$ \\
\hline cohabiting male & & & \\
\hline Same-sex & & & \\
\hline cohabiting female & $34.8 \%$ & $44.8 \%$ & $45.9 \%$ \\
\hline Total & & $53.3 \%$ & $51.7 \%$ \\
\hline
\end{tabular}

Table 9 indicates that for same-sex couples of all types between ages 45 and 64, a smaller percentage of couples are likely eligible to claim spousal benefits than among similarly-aged heterosexual couples. For couples 65 and older, same-sex married men and cohabiting same-sex couples are also less likely to 
qualify for spousal benefits than heterosexual married couples, while same-sex married women are about equally as likely to qualify.

Next, Table 10 presents the estimated mean value of the additional monthly spousal SSA benefit awarded to the lower-income partner, (i.e., the amount in addition to the claimant's own SS benefit), among those who could hypothetically claim.

Table 10. Mean additional monthly dollar payment due to claiming spousal benefits (in current dollars), ACS 2011-2015

\begin{tabular}{|c|c|c|c|}
\hline Relationship type & Age 45-54 & Age 55-64 & Age 65+ \\
\hline Hetero married & 669 & 595 & 360 \\
\hline Hetero cohabiting & 464 & 448 & 424 \\
\hline $\begin{array}{l}\text { Same-sex married } \\
\text { male }\end{array}$ & 724 & 647 & 428 \\
\hline $\begin{array}{l}\text { Same-sex married } \\
\text { female }\end{array}$ & 600 & 599 & 380 \\
\hline $\begin{array}{l}\text { Same-sex } \\
\text { cohabiting male }\end{array}$ & 584 & 586 & 480 \\
\hline $\begin{array}{l}\text { Same-sex } \\
\text { cohabiting female }\end{array}$ & 554 & 552 & 385 \\
\hline Total & 652 & 587 & 362 \\
\hline
\end{tabular}

Table 10 suggests that same-sex married men are likely to be able to claim slightly larger spousal benefit amounts (between $\$ 50$ and \$70 more per month) than heterosexual married couples given that they are able to make a claim. However, as indicated in Table 7, a smaller proportion of male same-sex married couples are likely to qualify to make these claims. Same-sex married women appear able to claim 
similar, or possibly lower amounts than heterosexual married couples when they are able to make claims, although Table 7 also indicates they are likely to qualify than heterosexual couples as well. Table 8 also generally suggests that if same-sex cohabiting couples became legally married, current incomes suggest they would be able to claim smaller spousal benefit amounts than married heterosexuals, assuming they qualified to claim.

In sum, male same-sex married couples are less likely than heterosexual married couples to qualify for claiming spousal SS benefits - particularly among the current younger couples - but for those couples who are able to claim spousal benefits, they may be eligible to claim between $\$ 600$ to $\$ 840$ more per year than heterosexual married couples.

\section{Gay and Lesbian Population Projection: 2017-2040}

In order to estimate the numbers of LGB individuals at various ages in various years, we first needed to derive the proportions of each age/sex cell that consisted of LGB individuals, then apply those proportions to official U.S. Census population projections. Using national survey data designed to measure sexual orientation and behaviors, we identified an initial population ages 18 to 26 for which we had reliable sexual-orientation information. We then derived population projections based on this information separately for LGB and heterosexual populations in order to estimate the proportions of individuals 27 and older who are LGB. Finally, these proportions were applied to official national population projections.

Our first step was to estimate the national LGB population using a standard cohort component population projection model. Cohort component population projection is a standard demographic method of projecting populations based on births and deaths over time (Preston, Heuveline and Guillot 2001). The projection method accounted separately for births of gay/bisexual men and lesbian women, and heterosexual (and bisexual women) entering the population as they are born throughout the 
projection period. We also derived projections of the heterosexual population over the same period in order to identify the proportion of each age/sex group that was LGB.

Baseline populations: We used several sources of data to generate the estimates. First, we used the National Longitudinal Study of Adolescent to Adult Health (Add Health) to assess the proportion of LGB individuals in the population at ages 18 to 26 . Add Health is a longitudinal study that has expended effort to collect detailed measures of sexual orientation, and it previously has been used to generate national estimates of this population (Meadows et al. 2010). Add Health estimates suggest that gay men represent 2.5 percent of the male population in these ages, while bisexual men represent 0.6 percent. Lesbian women and bisexual women represent 1.9 percent and 2.5 percent of women in these ages, respectively.

These proportions were then applied to the 2010 U.S. Census population counts by age and sex to derive numbers of LGB individuals in the U.S. in 2010, 26 and younger. (We do not know the proportion of older adults who are LGB at this stage.) The resulting 2010 population estimates were used as the baseline LGB population. This baseline population was subtracted from the total U.S. population (by age and sex) in order to identify the heterosexual population for similar models.

Births: Births of LGB individuals are identified and added to the LGB population (and subtracted from the heterosexual population) over time by applying age-specific fertility rates (Martin et al. 2017) to the heterosexual population.

Deaths: Recent research indicates that sexual orientation is associated with differential mortality rates among U.S. adults ages 18 to 59 (Cochran, Bjorkenstam, and Mays 2016). Specifically, gay and bisexual males experience mortality rates 2.2 times higher than heterosexual males; lesbian women experience mortality rates that are 3.2 times as high as heterosexual and bisexual women. These differences are due almost entirely to differential health and health behaviors between these populations. 
In order to derive mortality rates for the LGB populations, we adjusted the official 2010 U.S. National Vital Statistics Report mortality rates for men and women ages 18 to 59 (Murphy, Xu, and Kochanek 2013) to reflect the higher mortality rates for gay and bisexual men and lesbian women. We estimated two models: one with higher mortality only for the ages 18-59 reported in the Cochran, Bjorkenstam, and Mays (2016) study, and one where the increased mortality risks are also maintained at ages 60 and older.

Projections of both the LGB and the heterosexual population were estimated until the relative proportions of LGB individuals in each age/sex cell stabilized in subsequent years (i.e., once the baseline populations in 2010 had aged out far enough that the initially unknown proportions of LGB individuals 27 and older are estimated). This activity was performed with the U.S. Census Bureau’s Rural and Urban Projection software ${ }^{4}$ and generated yearly estimates of the national LGB and heterosexual populations between 2010 and 2070.

The resulting stabilized proportions of the population that are gay or bisexual men, and lesbian women, by age and sex, are shown in Table 11.

\footnotetext{
4 https://www.census.gov/population/international/software/rup/
} 
Table 11. Proportions of the population that are LGB by age and sex under three mortality regimes

A. Same mortality rates for LGB and heterosexuals at all ages
\begin{tabular}{lllllllllllll} 
& $30-34$ & $35-39$ & $40-44$ & $45-49$ & $50-54$ & $55-59$ & $60-64$ & $65-69$ & $70-74$ & $75-79$ & $80-84$ & $85-89$ \\
\hline Male & 0.031 & 0.031 & 0.031 & 0.031 & 0.031 & 0.031 & 0.031 & 0.031 & 0.031 & 0.031 & 0.031 & 0.031 \\
Female & 0.019 & 0.019 & 0.019 & 0.019 & 0.019 & 0.019 & 0.019 & 0.019 & 0.019 & 0.019 & 0.019 & 0.019
\end{tabular}

B. Increased LGB mortality rates until age 60

\begin{tabular}{lllllllllllll} 
& $30-34$ & $35-39$ & $40-44$ & $45-49$ & $50-54$ & $55-59$ & $60-64$ & $65-69$ & $70-74$ & $75-79$ & $80-84$ & $85-89$ \\
\hline Male & 0.031 & 0.031 & 0.031 & 0.030 & 0.029 & 0.028 & 0.027 & 0.027 & 0.027 & 0.027 & 0.027 & 0.028 \\
Female & 0.019 & 0.019 & 0.019 & 0.018 & 0.018 & 0.017 & 0.016 & 0.016 & 0.016 & 0.016 & 0.016 & 0.017
\end{tabular}

C. Increased LGB mortality rates at all ages

\begin{tabular}{lllllllllllll} 
& $30-34$ & $35-39$ & $40-44$ & $45-49$ & $50-54$ & $55-59$ & $60-64$ & $65-69$ & $70-74$ & $75-79$ & $80-84$ & $85-89$ \\
\hline Male & 0.031 & 0.031 & 0.031 & 0.030 & 0.029 & 0.028 & 0.026 & 0.024 & 0.021 & 0.017 & 0.012 & 0.004 \\
Female & 0.019 & 0.019 & 0.019 & 0.018 & 0.018 & 0.017 & 0.016 & 0.014 & 0.012 & 0.009 & 0.006 & 0.001
\end{tabular}

Panel A presents the proportions in each age/sex cell assuming there are no differences in mortality rates between LGB and heterosexual individuals. Panel B applies increased LGB mortality rates from ages 18 to 59, and Panel $\mathrm{C}$ extends the increased mortality rates to 60 and older.

Note that because we assume the mortality rates of bisexual women are the same as heterosexual women, the proportions expected to be bisexual remains 0.025 at each age. Also note that differences between Panels A and B are relatively minor: although mortality risk is elevated for ages 18 to 59, the baseline mortality risks during these ages are quite low, resulting in only minor shifts in population compositions. Panel C, in which mortality risk is elevated past age 60, shows dramatic changes in population composition relative to the other two. Subsequently, we focus on the models with equal mortality risk (Panel A) and with consistently elevated mortality risk (Panel C).

The resulting proportions by age and sex were then applied to the official 2014 U.S. Census projections of the national population (the most current available) to estimate the numbers of LGB individuals by age and sex over time. Applying our proportional estimates of the LGB population to the U.S. Census Bureau projections allows us to add in- and out-migration, as well as anticipated trends in fertility levels, over time (U.S. Census Bureau 2016). Note that this step assumes that there are no significant differences in the in- and out-migration patterns of LGB individuals relative to heterosexuals. 
Total population: In Table 12 we present two estimates of gay male and lesbian female populations

based on the population proportions derived above, first (our upper bound estimate) under the

assumption there are no mortality rate differences (Panel A, above), and second (our lower bound

estimate), under the assumption that mortality rates are consistently elevated for LGB individuals (Panel

B).

Table 12. Gay and lesbian population projections by age, 2017-2040

A. Projected Gay \& Lesbian Populations, Ages 55+: 2017-2040 (Standard Mortality Risk)

\begin{tabular}{|c|c|c|c|c|c|c|c|c|c|c|c|c|}
\hline & \multicolumn{5}{|c|}{ Gay Males } & \multicolumn{7}{|c|}{ Lesbian Females } \\
\hline & $20-54$ & $55-61$ & $62-65$ & $66-70$ & $71-84$ & $85+$ & $20-54$ & 55-61 & $62-65$ & $66-70$ & $71-84$ & $85+$ \\
\hline 2017 & $1,953,291$ & 369,361 & 182,156 & 196,223 & 270,913 & 57,249 & $1,427,970$ & 298,206 & 152,282 & 167,743 & 255,724 & 79,823 \\
\hline 2020 & $1,975,217$ & 371,369 & 195,669 & 204,832 & 317,782 & 60,797 & $1,436,670$ & 298,895 & 162,883 & 176,136 & 295,895 & 81,599 \\
\hline 2025 & $2,028,970$ & 351,155 & 203,790 & 231,456 & 388,209 & 70,047 & $1,467,510$ & 280,380 & 168,618 & 197,694 & 360,549 & 88,914 \\
\hline 2030 & $2,094,906$ & 341,408 & 188,766 & 240,345 & 456,783 & 87,559 & $1,507,506$ & 271,899 & 154,764 & 203,855 & 423,219 & 106,959 \\
\hline 2035 & $2,157,018$ & 341,961 & 190,561 & 224,098 & 501,175 & 115,835 & $1,544,510$ & 269,821 & 155,764 & 188,015 & 462,253 & 138,233 \\
\hline 2040 & $2,207,626$ & 375,452 & 185,074 & 223,999 & 511,782 & 142,383 & $1,573,762$ & 292,202 & 149,798 & 187,275 & 468,186 & 169,832 \\
\hline
\end{tabular}

B. Projected Gay \& Lesbian Populations, Ages 55+: 2017-2040 (Increased Mortality Risk)

\begin{tabular}{|c|c|c|c|c|c|c|c|c|c|c|c|c|}
\hline & \multicolumn{5}{|c|}{ Gay Males } & \multicolumn{7}{|c|}{ Lesbian Females } \\
\hline & $20-54$ & $55-61$ & $62-65$ & $66-70$ & $71-84$ & $85+$ & $20-54$ & $55-61$ & $62-65$ & $66-70$ & $71-84$ & $85+$ \\
\hline 2017 & $1,873,447$ & 327,134 & 150,039 & 148,130 & 152,652 & 7,387 & $1,406,486$ & 262,465 & 124,462 & 120,053 & 126,195 & 4,201 \\
\hline 2020 & $1,895,732$ & 328,669 & 161,081 & 154,937 & 180,446 & 7,845 & $1,416,020$ & 262,929 & 132,999 & 126,330 & 147,693 & 4,295 \\
\hline 2025 & $1,949,515$ & 310,551 & 167,641 & 174,988 & 218,227 & 9,039 & $1,446,989$ & 246,474 & 137,533 & 141,691 & 178,096 & 4,680 \\
\hline 2030 & $2,014,917$ & 301,959 & 155,172 & 181,499 & 253,817 & 11,299 & $1,486,007$ & 239,073 & 126,070 & 145,934 & 206,080 & 5,629 \\
\hline 2035 & $2,073,720$ & 302,903 & 156,658 & 169,081 & 276,091 & 14,947 & $1,521,531$ & 237,508 & 126,932 & 134,442 & 222,411 & 7,275 \\
\hline 2040 & $2,120,583$ & 332,514 & 152,289 & 168,955 & 277,341 & 18,373 & $1,549,526$ & 257,177 & 122,234 & 133,902 & 220,667 & 8,939 \\
\hline
\end{tabular}

Under the assumption that there are no differences in mortality risk, we estimate that the total population of gay males 20 and older will increase from roughly 3 million in 2017 to 3.6 million in 2040. The population of gay males 55 and older will increase from 1.08 million in 2017 to 1.44 million in 2040, and the proportion of gay men older than 65 will increase from 0.17 to 0.24 . For lesbian women, we estimate that the population 20 and older will increase from 2.4 million in 2017 to 2.8 million in 2040. The increase in those 55 and older is from 0.95 million in 2017 to 1.27 in 2040, and the proportion older than 65 increases from 0.12 to 0.16 . 
Under the assumption that mortality rates for gay and lesbian individuals are higher than they are for heterosexuals, population increases are reduced: The total gay male population 20 and older increases from 2.7 million in 2017 to 3.1 million in 2040, and lesbian women 20 and older increase from 2.0 million to 2.3 million. Gay males 55 and older increase from 0.79 million in 2017 to 0.95 million in 2040; for lesbian women the increase is from 0.64 million to 0.74 million. The proportions of each older than 65 shift from 0.12 to 0.15 for men and 0.12 to 0.016 for women over this time period.

Note that the total U.S. population 20 and older is projected to increase from 244 million in 2017 to 293 million in 2040; under either mortality regime the proportion of the population that is gay or lesbian remains less than 2 percent.

These estimates provide baselines from which to estimate the numbers of same-sex marriages that can potentially impact Social Security claims. In 2016, Gallup estimated that 10.5 percent of gay men and 8.8 percent of lesbian women were married. It is possible that these percentages will increase over time as younger gays and lesbians marry more than in the past when it was less available, but it does provide a starting point for estimating the numbers of married gay men and women who will reach retirement age. For example, this suggests that there are currently between 477,000 and 552,000 gay men ages 55 to 65 nearing or at retirement, of whom roughly 50,000 to 60,000 may be or have been married. Similar figures for lesbian women are 387,000 to 450,000 , of whom 34,000 to 40,000 are or have been married.

Based on our ALP survey, an estimated 50 percent of gay and men and women intend to marry, or are already married, suggesting larger numbers in the future. This suggests that by 2040 there may be between 1.6 and 1.8 million married (or previously married) gay men and between 1.2 and 1.4 million married (or previously married) gay women. Among the retirement-age population 66 and older in 2040, these numbers suggest more than 300,000 same-sex marriages will have been experienced, assuming the midpoint population between high- and low-mortality regimes. 
By focusing on individuals approaching retirement age (62 to 65) and assuming the rate of gay marriage does reach the projected 50 percent, we can derive a ballpark figure of Social Security spousal benefits. A rough estimate of 40 percent of male same-sex married couples are anticipated to be able to claim spousal benefits (Table 9) amounting to roughly $\$ 700$ per month (Table 10). In 2017, this suggests annual spousal Social Security payments between \$126-153 million could be due to this group (under the high mortality and low mortality regimes, respectively) ${ }^{5}$. In 2030, similar estimates are between \$130-159 million, and in 2040 between $\$ 128$ to \$155 million. Similar estimates for married same-sex women are $\$ 90$ to $\$ 110, \$ 91$ to $\$ 111$, and $\$ 88$ to $\$ 108$ million in each time period, respectively.

If we wish to extend these calculations to the populations 66 and older in order to include all gay and lesbian individuals past retirement age, and we assume that by 2030 the estimated 50 percent marriage rate has been reached, we still need to make additional strong, simplifying assumptions about the duration of marriages and mortality within marriages to derive estimates. If a marriage is dissolved, spousal benefits are only available if the marriage lasted 10 or more years. We do not have information on the duration of same-sex marriages. Presumably not all same-sex marriages will last the required 10 years, and thus the spousal benefits will not be available to all previously married individuals. Here we will assume all marriages remain intact to facilitate calculations, but this assumption will overestimate the resulting spousal benefit payments to these individuals. If a spouse dies, the surviving spouse is entitled to the deceased partner's full SS benefit (if it is greater than their own). ${ }^{6}$ We do not have information about survivorship in older same-sex couples, so to facilitate calculations, we will assume there are no periods of widowhood. This assumption will underestimate the resulting spousal benefit payments for these individuals. We can calculate the total annual spousal benefit expenditures if we

\footnotetext{
5 i.e., Half of the population age 62 to 65 is (or has been) married = 91,078 individuals (low-mortality scenarios). This translates to 45,539 married couples, of which 40 percent are eligible to claim spousal benefits of roughly $\$ 700$ each per month, for an upper estimate of \$153 million per year.

${ }^{6}$ Note that the amount depends on timing of survivor benefit claims; If benefits start at an earlier age than full retirement age, they are reduced by a fraction of a percent for each month before full retirement age. See www.ssa.gov/planners/survivors/survivorchatred.html
} 
make these strong assumptions, but we stress that these results should be suggestive only. In 2030, annual spousal benefit payments to gay men would be roughly \$375 to \$659 million, and \$258 to \$529 million to lesbian women. These amounts are hugely dependent on the mortality regimes in place, and more work is needed to measure the mortality patterns of older LGB individuals.

It is also worth keeping in mind that our estimates for spousal benefits according to couple type - while there is variation - are relatively similar for heterosexual and same-sex couples over all. Male same-sex married couples may be eligible to claim roughly 10 percent more than heterosexual married couples, and female same-sex married couples may be eligible to claim roughly 5 to 10 percent less.

\section{ALP data collection summary}

We fielded a new survey on a sample of 247 gay, lesbian, and bisexual individuals in the RAND American Life Panel Survey complemented with an equal-size sample of heterosexual individuals in July 2017. We also attempted to derive sexual orientation for respondents who previously answered “prefer not to say” (PNS) using romantic attraction and sexual history questions, but they generally suggested PNS respondents were more like heterosexuals than gays or lesbians (see below).

The survey gathered information from single individuals and their partners (married or not) on earnings and labor supply status, as well as individual information on sexual orientation based on selfidentification, attraction and experience, subjective expectations about marriage, labor supply, and the claiming of Social Security benefits, and knowledge of spousal benefits. Response rates of the LGB population were about 70 percent, totaling 174 responses.

The ALP is an internet-based panel of about 6,000 U.S. respondents 18 and older who regularly take surveys. In contrast to most internet panels, ALP respondents need not have internet access when they are initially recruited, reducing an important source of bias and making the sample more representative. For additional information about the ALP, refer to Pollard and Baird (2017). 


\section{Sample Description}

We start by describing our sample by gender and marital status. Out of a total of 526 respondents, 280 (53.2 percent) were females. Among men, 54.8 percent are married, 61.2 percent self-identify as heterosexuals and 22.8 percent self-identify as LGB. Among women, 51.2 percent are married, 54.8 percent self-identify as heterosexuals and 23.6 percent self-identify as LGB. Interestingly, the proportion of women that self-identifies as bisexuals is substantially higher than the proportion of men (14.5 percent versus 6.4 percent). We also observe a sizable fraction of men (15.9 percent) and women (21.6 percent) that prefer not to say (PNS) how they identify themselves. In a further effort to uncover sexual preferences of this latter group, we also asked the extent to which individuals felt attracted for people of the same sex and past sexual behaviors with other individuals of the same sex. Based on sexual attraction, we observe that 81 percent of men and 65 percent of women that prefer not to report sexual orientation are likely to be heterosexuals, with similar numbers arising from questions regarding past sexual experiences.

Table 13: Sample Descriptives LGB panel American Life Panel Survey

\begin{tabular}{|c|c|c|c|c|c|c|c|c|c|c|}
\hline \multirow{2}{*}{ Marital } & \multicolumn{5}{|l|}{ Males } & \multicolumn{5}{|l|}{ Females } \\
\hline & Hetero & LG & Bisex & PNS & Total & Hetero & LG & Bisex & PNS & Total \\
\hline Single & & & & & & & & & & \\
\hline $\mathbf{N}$ & 46.3 & 33.8 & 12.7 & 18.2 & 111.0 & 57.2 & 19.2 & 23.7 & 36.5 & 136.6 \\
\hline$\%$ & 30.7 & 83.3 & 81.4 & 46.3 & 45.1 & 37.3 & 76.0 & 58.1 & 60.2 & 48.8 \\
\hline Married & & & & & & & & & & \\
\hline $\mathbf{N}$ & 104.3 & 6.8 & 2.9 & 21.0 & 135.0 & 96.2 & 6.1 & 17.1 & 24.1 & 143.4 \\
\hline$\%$ & 69.3 & 16.7 & 18.6 & 53.7 & 54.9 & 62.7 & 24.1 & 41.9 & 39.8 & 51.2 \\
\hline Total & 150.6 & 40.6 & 15.7 & 39.2 & 246.0 & 153.4 & 25.3 & 40.8 & 60.6 & 280.0 \\
\hline$\%$ & 61.2 & 16.5 & 6.4 & 15.9 & 100.0 & 34.3 & 9.0 & 14.5 & 21.6 & 100.0 \\
\hline
\end{tabular}




\section{Subjective expectations of marriage, divorce, and relationship stability}

Table 14 describes subjective expectations about marriage for the sub-sample of single individuals, by sexual orientation, reporting the percentage chance they will: a) ever get married, b) marry in the next five years, and c) marry in the future because the federal law was passed in June 2015. Overall, gay men report similar expectations about marriage in the future to heterosexual men, both "ever" (46.1 percent versus 41.1 percent) and "in the next five years" (32.4 percent versus 34.9 percent). Percentages for lesbians are somewhat smaller both in "ever" (41.6 percent versus 38 percent) and "in the next five years” (37.9 percent versus 26.2 percent). While we do not expect heterosexuals to change their expectations about marriage because of the federal law, 44.1 percent of gay males and a 34.4 percent of lesbians would marry because of the new institutional framework. Finally, bisexual women are more likely to get married than bisexual men (53.9 percent versus 25.0 percent). Overall, combining the information of current marriage rates among heterosexuals and gays-lesbians from Table 13 with subjective expectations about future marriage from Table 14, we observe a potential decrease in the marriage gap between the hetero and LGB population in the near future. This suggests that if the unmarried gay and lesbian individuals eventually do marry at the rates they expect, a total of 51 percent of gay men and 53 percent of lesbian women will eventually marry. Nationally, 77 percent of men and 83 percent of women 25 and older have ever married (Wang and Parker 2014).

Table 14: Subjective expectations about marriage, single individuals

\begin{tabular}{|c|c|c|c|c|c|c|c|c|c|c|}
\hline \multirow{2}{*}{$\begin{array}{l}\text { Chances that you will } \\
\text { get married (Singles) }\end{array}$} & \multicolumn{5}{|l|}{ Males } & \multicolumn{5}{|l|}{ Females } \\
\hline & $\mathbf{H}$ & LG & B & PNS & Total & $\mathbf{H}$ & LG & B & PNS & Total \\
\hline$\overline{\text { Ever }}$ & 46.1 & 141. & 125.0 & 58.4 & 444.2 & 41.6 & $\begin{array}{ll}6 & 38.0\end{array}$ & $\begin{array}{ll}0 \quad 53.9\end{array}$ & $\begin{array}{ll}9 & 53.8\end{array}$ & 46.2 \\
\hline $\begin{array}{l}\text { In the next } 5 \text { years } \\
\text { Because of the law }\end{array}$ & $\begin{array}{r}32.4 \\
0.0\end{array}$ & $\begin{array}{l}43 . \\
44 .\end{array}$ & $\begin{array}{ll}9 & 15.7 \\
1 & 10.4\end{array}$ & $\begin{array}{ll}76.9 \\
4 \quad 31.0\end{array}$ & $\begin{array}{ll}9 & 31.9 \\
0 & 33.5\end{array}$ & $\begin{array}{r}37.9 \\
0.0\end{array}$ & $\begin{array}{ll}9 & 26.2 \\
0 & 34.4\end{array}$ & $\begin{array}{ll}2 & 46.9 \\
4 & 18.9\end{array}$ & $\begin{array}{ll}9 & 39.1 \\
9 & 10.7\end{array}$ & $\begin{array}{l}38.0 \\
19.2\end{array}$ \\
\hline
\end{tabular}


Table 15 reports subjective expectations about marriage dissolution among married respondents.

Chances that the marriage will continue in the future are stable across sexual orientation types for men, but slightly smaller for bisexual women (81.9 percent versus more than 96 percent for hetero and lesbians).

Table 15: Subjective expectations about marriage dissolution, married individuals

\begin{tabular}{|c|c|c|c|c|c|c|c|c|c|c|}
\hline \multirow{2}{*}{$\begin{array}{l}\text { Chances that marriage } \\
\text { will continue }\end{array}$} & \multicolumn{5}{|l|}{ Males } & \multicolumn{5}{|l|}{ Females } \\
\hline & $\mathbf{H}$ & LG & B & PNS & Total & $\mathrm{H}$ & LG & B & PNS & Total \\
\hline $\begin{array}{l}\text { mean } \\
\text { sd }\end{array}$ & $\begin{array}{l}91.3 \\
16.4 \\
\end{array}$ & $\begin{array}{r}96.4 \\
-\quad 5.4 \\
\end{array}$ & $\begin{array}{r}96.4 \\
+\quad 9.1 \\
\end{array}$ & $\begin{array}{r}86.4 \\
32.9 \\
\end{array}$ & \begin{tabular}{|l|}
90.9 \\
19.5 \\
\end{tabular} & $\begin{array}{r}96.7 \\
9.6 \\
\end{array}$ & $\begin{array}{r}99.5 \\
0.9 \\
\end{array}$ & $\begin{array}{l}81.9 \\
30.9 \\
\end{array}$ & $\begin{array}{l}92.1 \\
15.0 \\
\end{array}$ & $\begin{array}{l}94.2 \\
15.4 \\
\end{array}$ \\
\hline $\mathbf{N}$ & 85 & 11 & 6 & 16 & 118 & 71 & 6 & 17 & 19 & 113 \\
\hline
\end{tabular}

We further assess subjective expectations about relationship stability by sexual orientation by asking married or partnered respondents to report the percentage change that the current relationship will be permanent. Table 16 shows that in general individuals of all sexual preferences are optimistic about the future of their relationship, with gay men slightly less certain about the relationship being permanent than their heterosexual counterparts (86.6 percent versus 90 percent), and lesbians with a more pronounced gap (82.7 percent versus 90.7 percent). Importantly, while bisexual men show a much lower certainty about relationship stability (81.7 percent), this figure is far more optimistic than that observed for bisexual women (57.32 percent).

Table 16: Subjective expectations about relationship stability, partnered individuals.

\begin{tabular}{l|rrr|rrr}
\hline & \multicolumn{3}{|l}{ Males } & & \multicolumn{3}{|l}{ Females } \\
Chances that the relationship is permanent & H & LG & B & & \multicolumn{3}{l}{ LG } & \multicolumn{1}{l}{ B } \\
\hline \hline Almost certain & 90.01 & 86.57 & 81.68 & 90.69 & 82.69 & 57.32 \\
A good chance & 9.54 & 13.43 & 18.32 & 6.57 & 8.88 & 14.35 \\
A 50-50 chance & 0.45 & 0 & 0 & 0.34 & 8.43 & 15.94 \\
Almost no chance & 0 & 0 & 0 & 2.4 & 0 & 12.39 \\
\hline Total & 100 & 100 & 100 & 100 & 100 & 100 \\
\hline \hline
\end{tabular}




\section{Subjective expectations about labor supply}

Table 17 depicts respondents' subjective expectations about changes in their labor supply choices in the future. We ask this question separately for singles and married with a slight modification. Among singles, where we ask to report the chance they will stop working or move to another job after marriage, we observe similar percentages between heterosexual and gay men (23.1 percent and 19.8 percent) compared with bisexuals (12 percent), and a much higher rate among lesbians (36.8 percent) compared to hetero and bisexual women (29.3 percent and 27.0 percent). Among those married, we ask instead about the chances they will stop working or move to another job before retirement. Although our sample sizes are small, here we consistently find that both gay men and women are much more likely to change their labor supply status in anticipation of retirement compared with their heterosexual counterparts.

Table 17: Subjective expectations about changes in labor supply in the future

\begin{tabular}{l|rll|llll}
\hline SE of changes in labor supply & Males & & Female & & \\
& H & LG & B & H & LG & B \\
\hline \hline Stop working or move to another job & 23.1 & 19.8 & 12.0 & 29.3 & 36.8 & 27.0 \\
after marriage (singles) & & & & & & & \\
Stop working or move to a more & 36.8 & 62.5 & 15.4 & 52.0 & 79.5 & 56.0 \\
flexible job before retirement & & & & & & \\
\hline \hline
\end{tabular}

\section{Duration of relationships}

We next ask married and cohabitating respondents for the duration of their relationships. Table 18 shows that, while the sample size for LGB populations is very small, gay and lesbian couples have been in a long-term relationships for a substantially lower amount of time. On average, same-sex relationships for gay men is 11.9 years, compared with 17.9 years for heterosexuals and 26.4 years for bisexuals. In the case of women, the average duration for lesbians is 6.8 years, compared with 26.4 years for heterosexuals and 11.7 years for bisexuals. 
Table 18: Duration of relationships, married and cohabitating individuals

\begin{tabular}{l|rrr}
\hline Duration of & H & LG & B \\
\hline Males & & & \\
$\quad$ mean & 17.9 & 11.9 & 26.4 \\
sd & 15.7 & 9.1 & 7.6 \\
$\quad$ N & 89 & 28 & 7 \\
\hline Females & & & \\
mean & 26.4 & 6.8 & 11.7 \\
sd & 17.1 & 5.3 & 8.5 \\
N & 76 & 10 & 24 \\
\hline \hline
\end{tabular}

\section{Relative incomes of partners}

We investigate in our panel the extent to which earnings gaps between partners are replicable in the ALP, so we collect annual income data for respondents and their partners if they are married or cohabitating. In Table 19 we show that income patterns are similar to those reported in the ACS. Among men in married couples, the income gap in percentages among heterosexual couples is 65.2 percent, which is significantly higher than the gap for gay men (35.1 percent) and bisexuals (4.1 percent). As expected, the gap among heterosexual women is negative (-13.2 percent), compared with a positive gap among lesbians of 40.3 percent, very similar to the one reported by gay men. Overall, the ALP data on incomes suggests a lower degree of intrahousehold division of labor among gay couples. It also suggests that among single individuals, gay males earn significantly more than heterosexual men, but this needs to be further tested controlling for age and education. This is counter to earlier research on earnings of LGB versus heterosexual individuals (Black et al. 2003; Carpenter 2005), although note that we examine total income rather than earnings. 
Table 19: Individual and couple's annual income, regardless of labor supply status

\begin{tabular}{|c|c|c|c|c|c|c|c|c|}
\hline & \multicolumn{4}{|l|}{ Males } & \multicolumn{4}{|l|}{ Females } \\
\hline & Single & Married S & pouse & Diff & Single & Married S & Spouse & Diff \\
\hline \multirow[t]{3}{*}{ Hetero } & 27,083 & 57,267 & 34,673 & $65.2 \%$ & 38,858 & 45,836 & 52,801 & $-13.2 \%$ \\
\hline & 28,768 & 24,896 & 28,969 & & 27,337 & 34,442 & 30,540 & \\
\hline & 38 & 87 & 87 & & 76 & 73 & 70 & \\
\hline \multirow[t]{3}{*}{ LG } & 51,688 & 56,885 & 42,111 & $35.1 \%$ & 32,939 & 48,465 & 34,555 & $40.3 \%$ \\
\hline & 30,843 & 32,780 & 32,745 & & 22,103 & 23,530 & 28,885 & \\
\hline & 54 & 11 & 11 & & 27 & 6 & 6 & \\
\hline \multirow[t]{3}{*}{ B } & 29,901 & 45,251 & 43,458 & $4.1 \%$ & 32,716 & 31,975 & 28,523 & $12.1 \%$ \\
\hline & 29,837 & 30,893 & 32,960 & & 24,972 & 24,043 & 20,536 & \\
\hline & 23 & 6 & 6 & & 28 & 17 & 17 & \\
\hline \multirow[t]{3}{*}{ PNS } & 5,785 & 48,344 & 43,593 & $10.9 \%$ & 20,164 & 40,819 & 44,501 & $-8.3 \%$ \\
\hline & 8,108 & 31,208 & 27,711 & & 22,856 & 27,003 & 23,307 & \\
\hline & 10 & 16 & 16 & & 32 & 19 & 19 & \\
\hline Total & 31,366 & 55,598 & 36,625 & $51.8 \%$ & 32,408 & 43,453 & 47,640 & $-8.8 \%$ \\
\hline \multirow{2}{*}{$\begin{array}{l}\text { Income Diff \% } \\
\text { for married }\end{array}$} & 31,233 & 26,463 & 29,007 & & 26,029 & 31,866 & 29,252 & \\
\hline & 125 & 120 & 120 & & 163 & 115 & 112 & \\
\hline
\end{tabular}

We test for the hypothesis that earnings gaps in percentage of couple incomes are significantly different between LG and heterosexual couples in a regression framework. Similarly to Table 7, in Table 20 we report the results of regressions of income gaps in percentages of couple's incomes on dummies for sexual preferences and the interactions with couple's work status. We control for covariates such as couple’s work status, age polynomials, gender and education. The marginal-effects dummies for sexual preferences do not suggest significant differences between lesbian-gay male and hetero couples, nor between bisexual and hetero couples after controlling for couple’s labor supply status, confirming our results obtained from the ACS survey. 
Table 20: Regressions of income gaps in percent on sexual preferences, ALP.

\begin{tabular}{|c|c|c|c|}
\hline $\begin{array}{l}\text { Income Differential \% marrie } \\
\text { individuals }\end{array}$ & Coef. & Std. Err. & \\
\hline Sexual Orientation & & & \\
\hline LG & -3.478 & 3.443 & -1.01 \\
\hline B & -5.230 & 4.310 & -1.21 \\
\hline PNS & -3.932 & 3.004 & -1.31 \\
\hline Work Status & & & \\
\hline Respondent work & 11.567 & 2.003 & 5.78 \\
\hline Spouse work & -4.962 & 1.990 & -2.49 \\
\hline Both work & -4.804 & 1.779 & -2.7 \\
\hline Interactions & & & \\
\hline LG * Respondent works & -13.010 & 7.943 & -1.64 \\
\hline LG* Spouse works & 0.000 & - & \\
\hline LG * Both work & 7.564 & 4.102 & 1.84 \\
\hline B * Respondent works & -10.862 & 6.731 & -1.61 \\
\hline B * Spouse works & 7.881 & 5.760 & 1.37 \\
\hline B * Both work & 4.661 & 4.754 & 0.98 \\
\hline Age & 0.479 & 0.234 & 2.05 \\
\hline Age2 & -0.006 & 0.002 & -2.65 \\
\hline Female & -2.592 & 0.999 & -2.59 \\
\hline Highest education & 0.171 & 0.249 & 0.69 \\
\hline _cons & -0.010 & 6.436 & 0 \\
\hline $\mathbf{N}$ & 231 & & \\
\hline $\mathbf{F}$ & 9.460 & & \\
\hline R2 & 0.446 & & \\
\hline
\end{tabular}

Couple's work status and division of labor

Given the previous results, we further report differences in intrahousehold division of labor across different types of couples studying their work status. Individuals are classified as "working” if they supply at least one hour of labor per week. Table 21 shows the couple’s labor supply for males respondents and Table 22 the same for female respondents. Overall, we observe a lower degree of intrahousehold division of labor among same-sex couples as it is more likely that both partners are either working or not working. For example, in 90.5 percent of male same-sex couples both work and only in 
71.6 percent of heterosexual couples where the respondent is male that happens. These percentages are 94.5 percent and 89.9 percent among women.

Table 21: Couple's labor supply status for male respondents.

\begin{tabular}{|c|c|c|c|c|c|c|}
\hline \multirow[b]{2}{*}{$\begin{array}{l}\text { Respondent / Partner } \\
\text { work status (males) }\end{array}$} & \multicolumn{3}{|l|}{ Hetero } & \multicolumn{3}{|l|}{ LGB } \\
\hline & Not work & Work & Total & Not work & Work & Total \\
\hline $\begin{array}{l}\text { Not work } \\
\text { (\%) }\end{array}$ & $\begin{array}{r}9.6 \\
40.7\end{array}$ & $\begin{array}{l}14.0 \\
59.3\end{array}$ & $\begin{array}{r}23.6 \\
100.0\end{array}$ & $\begin{array}{r}4.7 \\
56.6\end{array}$ & $\begin{array}{r}3.6 \\
43.4\end{array}$ & $\begin{array}{r}8.3 \\
100.0\end{array}$ \\
\hline $\begin{array}{l}\text { Work } \\
(\%)\end{array}$ & $\begin{array}{l}23.4 \\
28.4\end{array}$ & $\begin{array}{l}59.0 \\
71.6\end{array}$ & $\begin{array}{r}82.4 \\
100.0\end{array}$ & $\begin{array}{l}2.4 \\
9.5\end{array}$ & $\begin{array}{l}23.2 \\
90.5\end{array}$ & $\begin{array}{r}25.7 \\
100.0\end{array}$ \\
\hline Total & $\begin{array}{l}33.0 \\
31.2 \\
\end{array}$ & $\begin{array}{l}73.0 \\
68.9 \\
\end{array}$ & \begin{tabular}{l|}
106.0 \\
100.0 \\
\end{tabular} & $\begin{array}{r}7.2 \\
21.1 \\
\end{array}$ & $\begin{array}{l}26.8 \\
78.9 \\
\end{array}$ & $\begin{array}{r}34.0 \\
100.0 \\
\end{array}$ \\
\hline
\end{tabular}

Table 22: Couple's labor supply status for female respondents.

Females

\begin{tabular}{l|llr|lrr|}
\hline Respondent / Partner & \multicolumn{1}{l}{$\begin{array}{l}\text { Hetero } \\
\text { Not work }\end{array}$} & Work & Total & $\begin{array}{l}\text { LGB } \\
\text { Not work }\end{array}$ & Work & Total \\
work status (females) & & & & & & \\
\hline \hline Not work & 20.8 & 13.3 & 34.2 & 7.7 & 10.4 & 18.0 \\
& 61.0 & 39.0 & 100.0 & 42.5 & 57.5 & 100.0 \\
Work & & & & & & \\
& 3.8 & 36.0 & 39.8 & 3.4 & 37.6 & 41.0 \\
& 10.1 & 89.9 & 100.0 & 5.5 & 94.5 & 100.0 \\
\hline Total & 24.7 & 49.3 & 74.0 & 11.0 & 48.0 & 59.0 \\
& 33.4 & 66.6 & 100.0 & 18.7 & 81.3 & 100.0 \\
\hline \hline
\end{tabular}

As presented above, we also test for differences across types of couples in a regression approach in Table 23. Restricting the sample to couples in which at least one of the partners work, we run probit regressions for the probability that both are employed respect to the case in which only one partner is employed, on dummies for sexual preferences, controlling for age, gender, and education. Our results 
are slightly different from those reported from ACS data in Table 3. While the coefficients are positive and similar in magnitude, differences between LGB and heterosexual couples are not significant, but we attribute this to a lack of power resulting from a lower sample size. We conclude that observed patterns of higher intrahousehold division of labor are confirmed in our data, but more research is needed to understand the underlying factors behind the joint labor supply decision.

Table 23: Probit regression of couple's labor supply on sexual preferences

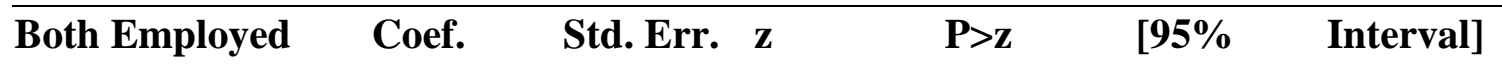

\begin{tabular}{|c|c|c|c|c|c|c|}
\hline \multicolumn{7}{|l|}{ Sexual Orientation } \\
\hline LG & 0.668 & 0.549 & 1.22 & 0.224 & -0.408 & 1.744 \\
\hline B & 0.188 & 0.341 & 0.55 & 0.581 & -0.480 & 0.856 \\
\hline PNS & 0.247 & 0.296 & 0.83 & 0.405 & -0.334 & 0.827 \\
\hline Age & 0.057 & 0.054 & 1.07 & 0.286 & -0.048 & 0.162 \\
\hline Age2 & -0.001 & 0.001 & -1.58 & 0.114 & -0.002 & 0.000 \\
\hline Female & 0.223 & 0.203 & 1.1 & 0.272 & -0.175 & 0.621 \\
\hline highesteducation & 0.135 & 0.051 & 2.65 & 0.008 & 0.035 & 0.235 \\
\hline _cons & -2.241 & 1.395 & -1.61 & 0.108 & -4.974 & 0.492 \\
\hline $\mathbf{N}$ & 191 & & & & & \\
\hline LR Chi & 32.7 & & & & & \\
\hline
\end{tabular}




\section{Anticipated retirement timing}

Table 24: Subjective expectations about claiming SS benefits.

\begin{tabular}{|c|c|c|c|c|c|c|c|c|}
\hline Start collecting SS & Singles & & & & Marri & & & \\
\hline Men & $50-61$ & $62-65$ & 66-70 & $>70$ & $50-61$ & $62-65$ & 66-70 & $>70$ \\
\hline$\overline{\mathbf{H}}$ & 14.77 & 36.89 & 58.27 & 57.84 & 14.8 & 36.9 & 58.3 & 57.8 \\
\hline LG & 21.29 & 34.16 & 42.69 & 35.87 & 21.3 & 34.2 & 42.7 & 35.9 \\
\hline B & 24.68 & 48.15 & 54.02 & 39.62 & 24.7 & 48.1 & 54.0 & 39.6 \\
\hline PNS & 52.37 & 57.79 & 61.85 & 62.50 & 52.4 & 57.8 & 61.8 & 62.5 \\
\hline Total & 24.68 & 41.77 & 55.02 & 51.60 & 24.7 & 41.8 & 55.0 & 51.6 \\
\hline Women & $50-61$ & $62-65$ & $66-70$ & $>70$ & $50-61$ & $62-65$ & $66-70$ & $>70$ \\
\hline$\overline{\mathbf{H}}$ & 15.32 & 41.43 & 60.04 & 45.83 & 15.3 & 41.4 & 60.0 & 45.8 \\
\hline LG & 29.73 & 47.85 & 73.17 & 44.04 & 29.7 & 47.8 & 73.2 & 44.0 \\
\hline B & 18.55 & 33.06 & 43.79 & 56.77 & 18.5 & 33.1 & 43.8 & 56.8 \\
\hline PNS & 20.42 & 42.94 & 44.60 & 51.24 & 20.4 & 42.9 & 44.6 & 51.2 \\
\hline Total & 18.90 & 41.33 & 55.90 & 48.55 & 18.9 & 41.3 & 55.9 & 48.5 \\
\hline
\end{tabular}

When we look at subjective expectations of retirement timing, gay and lesbian respondents tend to report greater intentions to retire at younger ages than heterosexuals, although the differences are not statistically significant. Heterosexual respondents are nonsignificantly more likely to intend to work past age 70 than gay and lesbian respondents. Retirement timing has strong implications for the amount of SS benefits individuals are entitled to receive; early retirement reduces the benefit, while late retirement increases it. In this report, we assume retirement at the NRA in order to derive estimates, but more data needs to be collected to examine this assumption. If gays and lesbians are more likely to retire early, as the ALP data suggest, then the SS benefits available to them will be reduced.

\section{Knowledge of Social Security spousal benefit policy}

We also asked respondents about their knowledge of spousal Social Security benefits. Specifically, we asked “According to current Social Security regulations: A married spouse may be entitled to Social Security retirement benefits of up to half of their retired partner's Social Security benefit (if it is more than their personal Social Security benefit); if a couple is divorced after 10 or more years of marriage, a 
former spouse may still be entitled to Social Security retirement benefits of up to half of their former spouse's Social Security benefit (if it is more than their personal Social Security benefit); and widows/widowers can claim the full amount of their deceased spouse's benefit (if they have not remarried). How would you rate your knowledge of Social Security spousal benefits after retirement?” Response options included: “No knowledge,” “a little knowledge,” “some knowledge,” “a lot of knowledge,” and “don’t know."

Among unmarried respondents, heterosexuals reported low levels of knowledge (84 percent of men reported no/little/don't know, as did 68 percent of women). Unmarried LGB respondents also reported low levels of knowledge (55 percent of men and 65 percent of women). Married respondents reported better, but still low levels of knowledge. Among heterosexuals, 50 percent of men reported no/little/don’t know, as did 47 percent of women. Among LGB respondents, the numbers were 54 percent and 61 percent, respectively.

\section{Conclusions}

This paper represents the first step in assessing the implications of nationally legalized same-sex marriage for Social Security retirement benefits.

1. Same-sex couples tend to have higher household earnings than heterosexual couples, especially male same-sex couples - largely due to more frequent dual-employment in same-sex households;

2. Same-sex married couples are less likely than heterosexual couples to qualify for additional spousal SS benefit payments;

3. However, given that they are eligible to claim, male same-sex married couples could generally claim slightly higher spousal benefit amounts than heterosexual couples (about $\$ 8,400$ per year, roughly \$1,200 more than heterosexual married couples), while female same-sex married couples could generally claim similar amounts as heterosexual couples in spousal SS benefits (about $\$ 7,200$ per year); 
4. The sizes of the gay and lesbian populations at and beyond retirement age are dependent on mortality rate assumptions, but we estimate in 2017 there are between 308,000-524,000 gay men 66 older, and 250,000-503,000 lesbian women. By 2040 these populations are anticipated to be 465,000-868,000 and 364,000 - 825,000, respectively. According to our new data collection, up to half of these populations intend to marry.

These results are based on numerous assumptions and relatively sparse data. The economic circumstances of LGB individuals, as well as the retirement and marriage/divorce histories and intentions of these populations, are in need of additional study and additional data collection on which to base findings. Despite these limitations, this analysis has provided initial insights into the economic circumstances of these populations, and should serve as a foundation for future work. 


\section{References}

Beaghen, M., \& Weidman, L. (2008). Statistical issues of interpretation of the American Community Survey's one-, three-, and five-year period estimates. U.S. Census Bureau. Retrieved from https://usa.ipums.org/usa/resources/MYE_Guidelines.pdf

Black, Dan A., Makar, Hoda R., Sanders, Seth G. \& Taylor, Lowell J. (2003). “The Earnings Effects of Sexual Orientation.” Industrial and Labor Relations Review 56: 449-469.

Carpenter, Christopher S. (2005). “Self-Reported Sexual Orientation and Earnings: Evidence from California.” Industrial Labor Relations Review 58: 258-273.

Cochran, S.D., Bjorkenstam, C., \& Mays, V.M. (2016). “Sexual orientation and all-cause mortality among US adults ages 18 to 59 years, 2001-2011.” American Journal of Public Health 106: 918-920.

Jones, Jeffrey M. (2016). “Same-Sex marriages up one year after Supreme Court Verdict” accessed online: http://news.gallup.com/poll/193055/sex-marriages-one-year-supreme-court-verdict.aspx

Joyner, Kara, Manning, Wendy \& Bogle, Ryan. (2013). “The Stability and Qualities of Same-Sex and Different-Sex Couples in Young Adulthood.” Bowling Green State University Center for Family and Demographic Research 2013 Working Paper Series.

Liefbroer, Aart C., Gerritsen, Liesbeth \& Gierveld, Jenny de Jong. (1994). “The influence of intentions and life course factors on union formation behavior of young adults.” Journal of Marriage and Family 56: 193-203.

Martin, J.A., Hamilton, B.E., Osterman, M.J.K, Driscoll, A.K. \& Mathews, T.J. (2017). “Births: Final Data for 2015.” National Vital Statistics Reports; Vol 66, No 1. Hyattsville, MD: National Center for Health Statistics. 2017.

Meadows, Sarah O., Nicole K. Eberhart, Michael S. Pollard, \& Rebecca L. Collins. 2010. “Sexual Orientation and Disclosure” in Sexual Orientation and U.S. Military Personnel Policy: An Update of RAND’s 1993 Study. RAND MG-1056-OSD.

Murphy, S.L., Xu, J., and Kochanek, K.D. (2013). “Deaths: Final Data for 2010.” National Vital Statistics Reports; Vol 61, No 4. Hyattsville, MD: National Center for Health Statistics. 2013.

Pollard, Michael S. and Matthew Baird. (2017). “The RAND American Life Panel: Technical Description.” RAND RR-1651. 
Preston SH, Heuveline P, Guillot M, Demography: Measuring and Modeling Population Processes, Malden, MA: Blackwell Publishers, 2001.

Schwarz, Hunter. (2015). “There are 390,000 gay marriages in the U.S. The Supreme Court could quickly make is half a million.” The Washington Post, https://www.washingtonpost.com/news/the-fix/wp/2015/04/28/heres-how-many-gay-marriagesthe-supreme-court-could-make-way-for/

U.S. Census Bureau. (2016). “2014 National Projections. Methodology, Assumptions, and Inputs for the 2014 National Projections.” https://www2.census.gov/programs-surveys/popproj/technicaldocumentation/methodology/methodstatement14.pdf

Waite, Linda \& Das Aniruddha. (2010) “Families, social life, and well-being at older ages.” Demography 47: S87-S109.

Wang, W. and Parker, K. (2014). “Record share of American have never married.” Accessed online: http://www.pewsocialtrends.org/2014/09/24/record-share-of-americans-have-never-married/ 


\section{Appendix A. Estimating Social Security Benefit Amounts}

Our estimation of Social Security benefit amounts is based on data obtained from the SSA benefits calculator. In order to apply the SSA calculator estimates to the entire ACS 2011-2015 dataset, we derived equations that closely approximate the SSA calculator results for individuals who retire at the normal retirement age.

Figure A1 shows the size of expected SS benefits if person retires at NRA, based on current income and current age, taken directly from the SSA calculator. Benefits are estimated for incomes between $\$ 3,000$ and $\$ 230,000$ per year and for those whose current age is $45,50,55,62$, and 66 .

Based on this data, we estimated the relationship between the expected benefits at retirement and current age and earnings, so that we can estimate the expected SS benefits for people with any current age and earnings. 
Figure A1. SSA Calculator Estimates of the SS Benefits at NRA

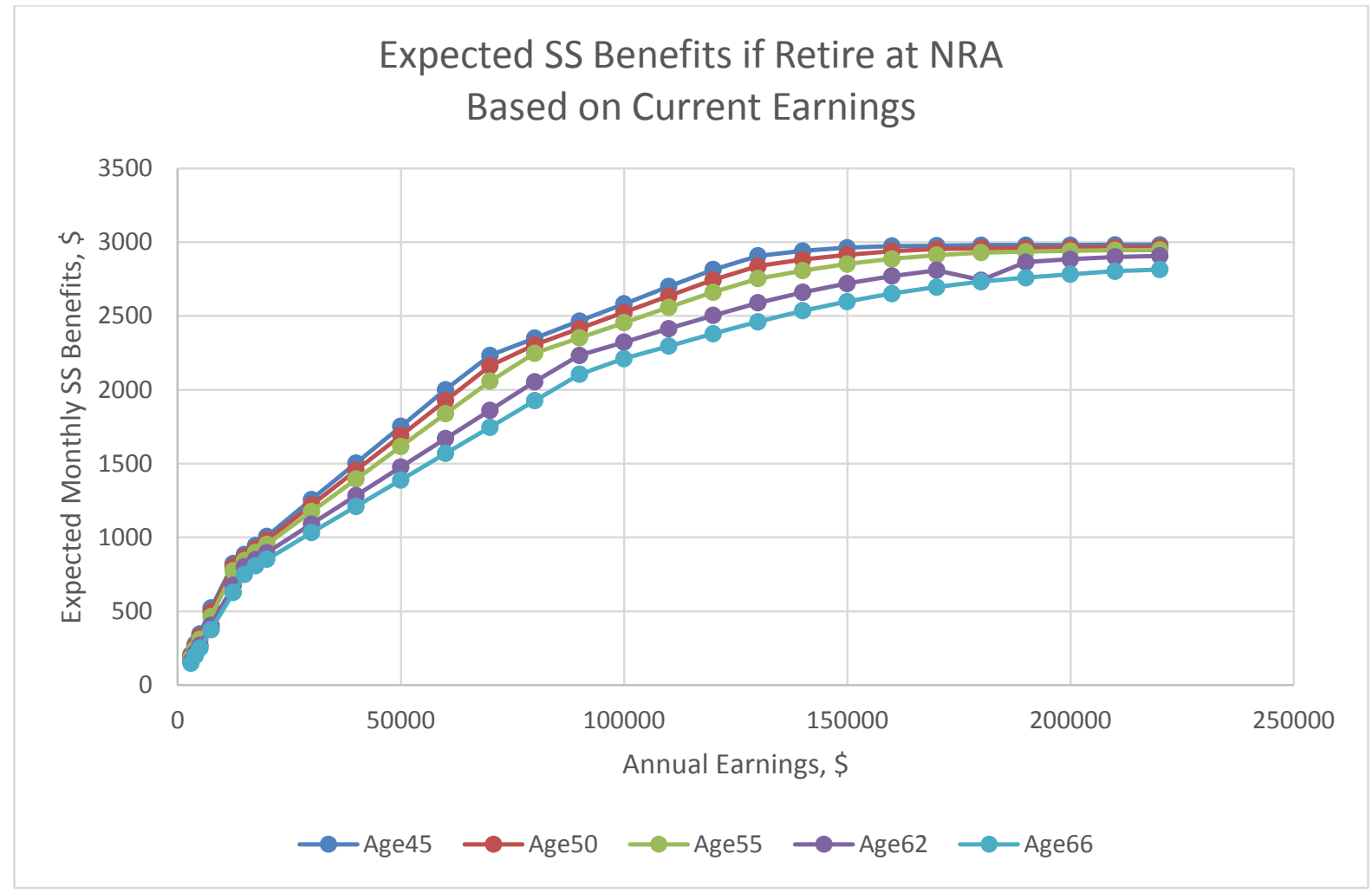

The relationship is roughly linear for earnings $\$ 0$ to $\$ 15,000$, linear but with different slopes for incomes of $\$ 15,000$ to approximately $\$ 85,000$, and then nonlinear (roughly second-order polynomial) for earnings above $\$ 85,000$. Benefits are capped at a constant level for earnings above $\$ 230,000$ per year.

We used multinomial regression to estimate a model that can be used for any combination of earnings and age to estimate potential SS benefits to apply to the ACS data. To account for different curve shapes, we introduced dummy variables and interactions. D1=1 if earnings are between 15,000 and 85,000 and 0 otherwise; D2=1 if earnings are more than 85,000 and 0 otherwise. Regression coefficients are presented in the table below: 
Table A1. Derived SS Benefit Equation Model

\begin{tabular}{|c|c|c|c|c|c|c|}
\hline \multicolumn{7}{|c|}{ SUMMARY OUTPUT } \\
\hline \multicolumn{7}{|c|}{ Regression Statistics } \\
\hline \multicolumn{7}{|c|}{ Multiple R 0.99931} \\
\hline \multirow{2}{*}{\multicolumn{7}{|c|}{$\begin{array}{l}\text { R Square } \\
\text { Adjusted R }\end{array}$}} \\
\hline & & & & & & \\
\hline \multicolumn{7}{|l|}{ Square } \\
\hline \multirow{2}{*}{\multicolumn{7}{|c|}{$\begin{array}{ll}\text { Standard Error } & 34.80442 \\
\text { Observations } & 200\end{array}$}} \\
\hline & & & & & & \\
\hline \multicolumn{7}{|l|}{ ANOVA } \\
\hline & $d f$ & SS & MS & $\boldsymbol{F}$ & $\begin{array}{l}\text { Significance } \\
F\end{array}$ & \\
\hline Regression & 11 & $1.65 \mathrm{E}+08$ & 14994169 & 12378.09 & 2.1E-262 & \\
\hline Residual & 188 & 227733.4 & 1211.348 & & & \\
\hline \multirow[t]{2}{*}{ Total } & 199 & $1.65 \mathrm{E}+08$ & & & & \\
\hline & Coefficients & $\begin{array}{l}\text { Standard } \\
\text { Error }\end{array}$ & $t$ Stat & P-value & Lower 95\% & $\begin{array}{l}\text { Upper } \\
95 \%\end{array}$ \\
\hline Intercept & 348.7273 & 46.27913 & 7.535302 & $2 \mathrm{E}-12$ & 257.4342 & 440.0204 \\
\hline Income & 0.05541 & 0.00141 & 39.28605 & $1.41 \mathrm{E}-92$ & 0.052628 & 0.058192 \\
\hline Age & -5.828 & 0.798667 & -7.29717 & 8.01E-12 & -7.4035 & -4.2525 \\
\hline D1 & 1067.28 & 59.51838 & 17.93193 & $1.44 \mathrm{E}-42$ & 949.8699 & 1184.689 \\
\hline D2 & 740.0844 & 267.3067 & 2.768671 & 0.006192 & 212.7784 & 1267.39 \\
\hline Incom_D1 & -0.03467 & 0.001428 & -24.2785 & 7.44E-60 & -0.03749 & -0.03186 \\
\hline Age_D1 & -9.93439 & 1.015682 & -9.78101 & $1.59 \mathrm{E}-18$ & -11.938 & -7.93079 \\
\hline Income_D2 & -0.04246 & 0.001662 & -25.5518 & 4.61E-63 & -0.04573 & -0.03918 \\
\hline Age_D2 & 35.22428 & 8.875632 & 3.96865 & 0.000103 & 17.71565 & 52.73291 \\
\hline Age_Income_D2 & 0.000107 & 1.12E-05 & 9.604688 & 5.04E-18 & 8.53E-05 & 0.000129 \\
\hline Income2_D2 & $-4.7 \mathrm{E}-08$ & 2.06E-09 & -22.6613 & $1.18 \mathrm{E}-55$ & $-5.1 \mathrm{E}-08$ & $-4.3 \mathrm{E}-08$ \\
\hline Age2_D2 & -0.5446 & 0.076681 & -7.1022 & $2.46 \mathrm{E}-11$ & -0.69587 & -0.39334 \\
\hline
\end{tabular}


Model performance: Figure A2 presents the relationship between SS benefits estimated from the SSA calculator (on the horizontal axis) versus benefits estimated from the regression model (the vertical axis). Points are tight along the 45-degree line, which means there is good model performance. Data include all ACS sample ages used for estimation.

Figure A2. In-sample SS Benefits Model Performance

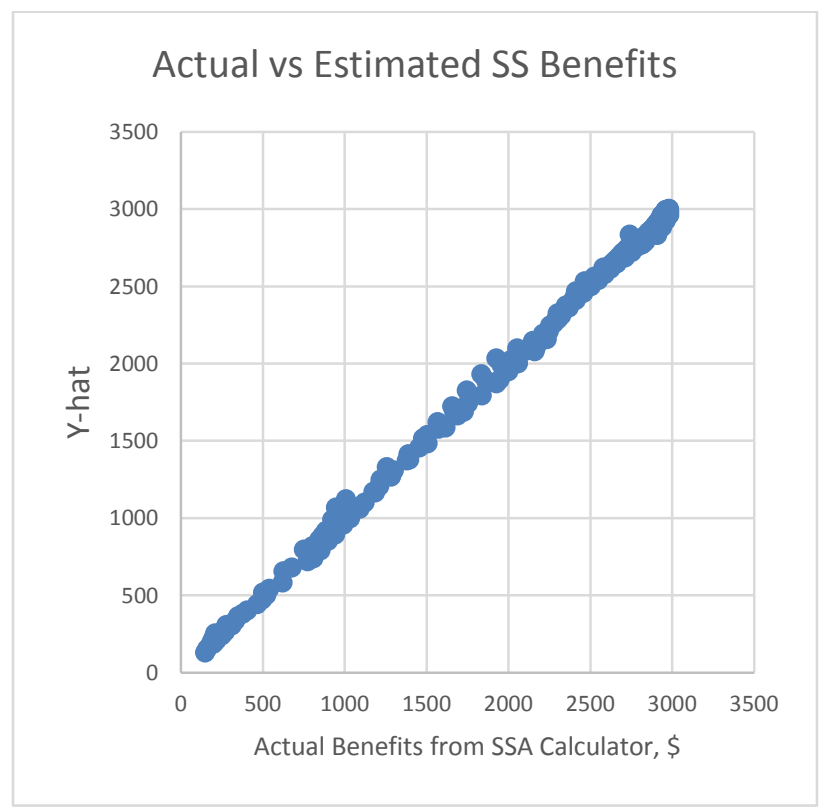


Figure 3A presents model performance for the data outside of the estimation sample - that is, for ages that were not originally used to derive the model in Table A1.

Figure 3A. Out-of-sample Model Performance for Three Ages

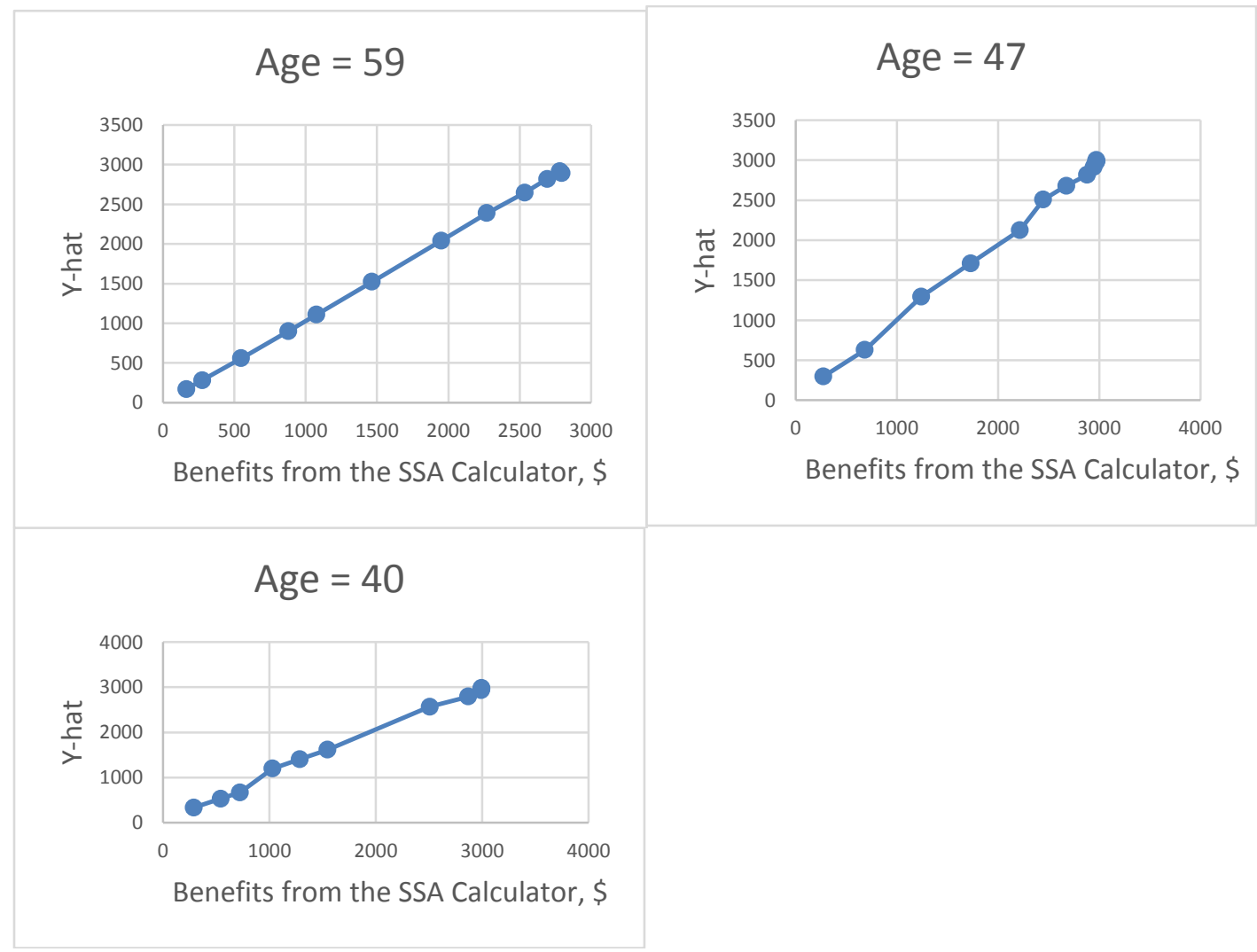

Again, the results closely follow the 45-degree line, indicating good performance.

Next, to estimate the additional Social Security spousal benefits that may be claimed by lowerearning partners, we applied the following procedure to the ASC data:

1. Use the model to estimate potential SS benefits based on current earnings and age;

2. Use actual SS benefits size for those whose data is available in ACS;

3. For every couple, estimate eligibility for claiming spousal benefits:

eligible if lower SSB < $(0.5 *$ higher SSB $)$; 
4. Estimate additional payment in case of claiming spousal benefits: $(0.5 *$ higher SSB $)$ lower SSB.

While the paper presents the results of this process for all ages, we suggest limiting interpretation of benefit amounts for ages 45 to 64, for which our model was estimated, and for those 65 and older due to actual data on SS benefits in ACS. Also, these calculations assume retirement at NRA. To the extent that there are differences in preferences for early or later retirement that vary between heterosexual and gay/lesbian individuals, actual SS benefit amounts may vary. This issue is one that warrants additional investigation, particularly given that the ALP results on retirement timing suggest preferences for earlier retirement for gay and lesbian individuals.

Note that this process assumes that the SSA benefits calculator is accurate for gay and lesbian individuals. The SSA calculator depends on internal estimates of earnings trajectories by age. If the earnings trajectories of heterosexuals differ from those of gay and lesbian individuals, given the same income at the same age, the calculator estimates of total eligible earnings will provide incorrect estimates of actual benefit amounts available. For example, if a 50-year old gay man earned the same amount as a 50-year old heterosexual man, but the earnings histories up to and/or after age 50 differed (i.e., the slopes on their income trajectories differed), the SSA calculator would incorrectly estimate the SS benefit amounts at NRA, and invalidate our comparisons of benefits between heterosexuals and gays and lesbians. ${ }^{7}$

As shown in Table 8, the assumption of similar earnings trajectories for LGB and heterosexual individuals is supported by longitudinal information from two decades of the HRS.

\footnotetext{
${ }^{7}$ We thank a reviewer at SSA for identifying this assumption.
} 